\title{
THE IMPLEMENTATION OF EXCHANGE OF INFORMATION IN THE BANKING INDUSTRY
}

\author{
FIRLY ROSALINI \\ MARIA R.U.D. TAMBUNAN \\ Department of Fiscal Administrative Science, Faculty of Administrative Science, Universitas Indonesia, Kampus UI \\ Depok, Indonesia \\ filyrosalini@gmail.com, maria.tambunan@ui.ac.id
}

\begin{abstract}
This study aims to analyze the implementation of Automatic Exchange of Information by Financial Institution especially at PT Bank XYZ Indonesia, a subsidiary of bank that serves over 38 million customers covers 66 countries worldwide, in Europe, Asia, the Middle East, and North Africa, North and Latin America. This study uses a qualitative approach with data collection through library and field research conducted by interviews with related parties. The results of the study show that Bank XYZ as a Reporting Financial Institution is required to implement the provisions of international reporting standards, namely Common Reporting Standard (CRS), which is used to classify data in accordance with its reporting objectives. Some obstacles were found, namely the need for further guidance issued by the Directorate General of Taxes as a competent authority that regulates in more detail the instructions for filling in reports to be reported when reporting financial information data, and also the Directorate General of Taxes must anticipate the possibility related problems when reported by the reporting financial institution.
\end{abstract}

Keywords: Exchange of information; automatic exchange of information; common reporting standard, financial institution

\begin{abstract}
Abstrak: Penelitian ini bertujuan untuk menganalisis implementasi pelaksanaan Automatic Exchange of Information yang dilaksanakan oleh Lembaga Keuangan Perbankan khususnya pada PT Bank XYZ. PT. Bank XYZ merupakan subsidiary sebuah bank berskala internasional yang telah memiliki 38 juta pelanggan yang tersebar di 66 negara, tersebar di Eropa, Asia, Timur Tengah, Afrika Selatan, Amerika Utara dan Amerika Selatan. Penelitian ini menggunakan pendekatan kualitatif dengan teknik pengumpulan data melalui studi kepustakaan dan studi lapangan yang dilakukan dengan wawancara dengan pihak-pihak terkait. Hasil penelitian menunjukkan Bank XYZ sebagai Lembaga Keuangan Pelapor diwajibkan untuk menerapkan ketentuan standar pelaporan internasional yaitu Common Reporting Standard (CRS) yang digunakan untuk mengklasifikasikan data sesuai dengan tujuan pelaporannya sebagai bentuk dari pelaksanaan kepatuhan transparansi global yang diinisiasi oleh OECD. Beberapa kendala yang ditemukan yakni perlu adanya guidance lebih lanjut yang dikeluarkan oleh Direktorat Jenderal Pajak sebagai pihak berwenang (competent authority) yang mengatur secara lebih rinci mengenai petunjuk pengisian laporan yang akan dilaporkan pada saat pelaporan data informasi keuangan, dan juga Direktorat Jenderal Pajak harus mengantisipasi kemungkinan terjadinya kendala terkait saat dilakukan pelaporan oleh Lembaga Keuangan Pelapor.
\end{abstract}

Kata kunci: Pertukaran informasi, pertukaran informasi otomatis, common reporting standard, institusi keuangan 


\section{INTRODUCTION}

The global economic integration has led to an increase in cross-country trading activities. The company has developed their strategies to maximize profit while minimizing the cost and expenditure, including tax. The Base Erosion and Profit Shifting (BEPS) Action Plan is an effort currently developed by the OECD to minimize tax avoidance, for example the practice of utilising the loopholes and limitations in the domestic tax regulation to "erase" the profit or transfer it to the other countries that have lower tax rates (OECD, Action Plan on Base Erosion and Profit Shifting, 2013). Besides the BEPS issue, tax avoidance and tax evasion issues often become the international concern, thus leading to cross-countries' tax authorities cooperation to tackle the issues through information sharing.

The OECD and other G2 countries member agreed to be the pioneer in implementing the taxation transparency in the form of information sharing. The OECD also set the main requirement for the automated exchange of information between countries by implementing the domestic regulation on the banking industry information openness. As a member of G20, the government of Indonesia released a Government's Regulation In Lieu of the Law (Perpu) of the Republic of Indonesia No 1 year of 2017 on Financial Information Access for Taxation Purposes that regulates the tax authorities to access the financial information, as well as the obligations of the financial companies and other entities to report their financial information automatically to the tax authority (Konsiderasi Peraturan Pemerintah Pengganti Undang-Undang Republik Indonesia Nomor 1 Tahun 2017, 2017). This regulation was legalized later through the enactment of Undang-Undang Nomor 9 Tahun 2017.

Automatic Exchange of Information (AEol)or the automatic information sharing implement particular information transfer of the taxpayer in particular timer periodically, systematically and continually from the source country or the place where the assets are located to the country where the taxpayer resides (Finansialku, 2017). The AEOI is implemented by following the scheme below:

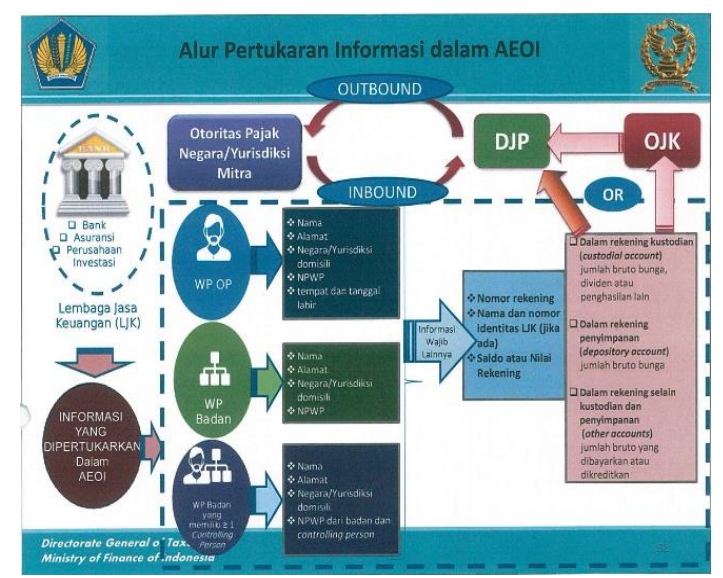

Figure 1.1 The Exchange of Information Chartflow in AEOI

Source: Presentation materials from the Focus Group Discussion Session: Indonesian Preparedness to the Automatic EOI: FATCA dan CRS Policies. The Ministry of Finance of the Republic of Indonesia.15 December 2016

According to the automatic information exchange flowcharts, the Directorate General of Taxes (DJP) receives data from Financial Services Agency including Bank, Insurance, or the investment companies which provides minimum information such as identity, the tax identification number, and the balance or the account value of individual or corporate taxpayer. The Financial Services Agency is obliged to classify the customers'data according to the reporting objectives for direct domestic reporting to the Directorate General of Taxes or international reporting to the Directorate General of Taxes through the Financial Services Authority. The data reporting by the Financial 
Services Agency should strictly follow the international reporting standards of Common Report Standard (CRS). This standard obliges the Financial Services Agency to report the financial account information in the form of a financial account of the taxpayers who reside in the foreign country to the Financial Services Authority of the country he/she resides.

Pertaining to the automatic financial information reporting, the Financial Agencies despite his obligation to report or not, should register themselves to the Directorate General of Taxes. After their registrations have been validated, the financial agency could perform their obligation to report the related customers' account information that should be exchanged for tax purposes to the Directorate General of Taxes. After the bank has been registered as the Financial Agency reporter, the bank should classify the type of the customers' account whether it is for domestic purpose or financial account that should be reported for international purpose according to the resident of the bank's customer. Another way to find the resident of the bank's customers is by requesting the Self Certification Form from the new customer who requests to open an account since July 1, 2017. Self-Certification is a formal declaration of the customer for the tax purpose (tax resident).

Bank $X Y Z$ is one of the Common Bank in the Financial Services Agency that has enacted the customers' account reporting policy to the Directorate General of Taxes, for the automatic information exchange purpose by implementing the policies as mentioned in the CRS. The bank is one of the biggest bank and financial services company in the world. Bank $\mathrm{XYZ}$ serves over 38 million customers through its 4 global businesses: Retail Bank and Wealth Management, Commercial Banking, Banking, and Global Market, and Global Private Banking. The network of Bank XYZ covers 66 countries and area in Europe, Asia, the Middle East, and North Africa, North and Latin America. Bank XYZ is a foreign bank from a country in the Middle East. The Bank initially entered Indonesia in
1884 by setting up its branch office of Foreign Bank XYZ in Indonesia. Until 2009 Bank XYZ has acquired the local bank with its vast network in Indonesia, thus in 2016 Bank XYZ in Indonesia has legally become an Indonesian body corporate with the name of Bank XYZ. Therefore, this study analyzes the impact of AutomaticExchange of Information (AEOI) on the banking business with a case study of Bank $\mathrm{XYZ}$.

\section{RESEARCH METHOD}

This research used qualitative method which is intended to explore the understanding on the phenomenon. On this research, the use of qualitative method is aimed to gain the understanding pertaining to the implementation of an enacted policy, that is the implementation of Automatic Exchange of Information on banking business (by taking a case study in a subsidiary of an MNE located in Indonesia. On qualitative research, the theory is not the main tools to be proved, instead theory is a tools of research framework. Further, this qualitative research is means of exploring the human or social issues through the creation of comprehensive and complex pictures, presented in words and delivers the natural and detailed perspectives (Haradhan, 2018). The data collection for this research was perceived through a literature study, documentation study and related regulations as well as an in-depth interview with the policymakers, tax authority and stakeholders.

\section{RESULTS AND DISCUSSION}

\section{Tax Avoidance and Tax Evasion}

Tax Avoidance is an effort to avoid and/or reduce the payable tax obligation by utilizing loopholes in the current tax law so that the taxpayer can pay a lower tax. This act is a violation of the law. Tax avoidance is an effort to avoid or reduce the tax which is still under the scheme of regulations. Avoidance involves 
commercialization and effective utilization of the tax regulation which is legitimate technically deviates and ambiguous (Adebisi \& Gbegi, 2013). Tax Evasion is an illegal act against the law which covers the deliberate act of not completely and correctly reports the tax object or any other illegal actions (Adebisi \& Gbegi, 2013). Tax evasion includes an act of payable tax fraud to avoid tax obligation (Balafoutas, Beck, Rudolf, \& Sutter, 2015). One of the examples of this act is by reducing the under declare revenue or even to report or manipulate the loses so that the income tax becomes smaller and finally the payable tax will be smaller or even completely not taxed (Adebisi \& Gbegi, 2013)

\section{The Exchange of Information}

The exchange of information is the information sharing related to the tax as agreed according to the international treaty or Exchange of Information (EOI) as the implementation of the International Agreement (Gadzo and Klemenic, 2017; Akhtar, 2018). For Indonesia context, the implementation of EOI is aimed to fulfill the Regulation of the Directorate General of Taxes No PER-28/PJ/2017,2017 that is intended to:

1) To prevent tax avoidance;

2) To prevent tax evasion;

3) To prevent the abuse of P3B by parties that have no right to that; and/or

4) To receive information related to the taxpayer's obligation fulfillment

Issues on transparency and information exchange have become an international concern. According to OECD (2006), there are several objectives for the exchange of information. First, the exchange of information is conducted to confirm the facts in relations to income tax convention regulations that should be enacted. Secondly, the information is being exchanged to assist one of the party in the treaty to manage and act according to the domestic tax law (OECD, Manual On The Implementation of
Exchange of Information Provisions For Tax Purposes, 2006)

\section{Forms of Exchange of Information}

There are five forms of exchange of information conducted by the country partner of P3B as regulated in the article 26 OECD consists of: 1) Exchange of Information on Request, 2) Spontaneous Exchange of Information, 3) Automatic (or Routine) Exchange of Information, 4) Industry-Wide Exchange of Information, 5) Tax Examination Abroad.

In this study, the author focuses on the forms of exchange of information in Indonesia, regulated in PER-67/PJ/2009 which was revised in PER 28/PJ/2017 that is (Regulation of the Directorate General of Taxes No PER-67/PJ/2009 jo PER28/PJ/2017,2017) :

1) Exchange of Information on Request); is the exchange of information related to tax issues requested by the Indonesian tax authority to the authority of the country partner or jurisdiction or vice versa.

2) Spontaneous Exchange of Information; is the exchange of information which is conducted spontaneously by the Indonesian government to the country partner of P3B or vice versa. The information is gathered from the result of tax examination and/or investigation by the country partner who shares the information.

Automatic Exchange of Information is an exchange of information conducted automatically and regularly on various types of income received by the taxpayer in the form of dividend, interest, royalty, wages, pension and other income which is sent systematically and periodically by the Competent Authority (CA) of the country that provides the income or the source country to the CA of the country where the receiver resides. 


\section{Concept and the Objectives of the Automatic Exchange of Information}

AEOI is a financial exchange of information program pertaining to tax, which is conducted periodically, automatic and comprehensive. The financial information being shared is the financial information of the foreign citizens who permanently reside in a particular country and shared to the tax authority of the country where the person has their nationality (Urinov, 2015). The exchange of information is automatic as it is conducted regularly (e.g. annually) and the information being exchanged has received permission from the taxpayer previously and not an exchange of information that is conducted by special request (OECD, Automatic Exchange of Information: A Roadmap for Developing Country Participation, 2014). The source countries are regularly collecting and reporting the related information pertaining to the third party (e.g. the financial agency) in the area where non-resident generates the income. The source country will also be able to verify the exchanged information accurately to the country where the taxpayer has their nationality (Urinov, 2015).

OECD divides the basic process of the exchange of information into seven parts, i.e. (OECD, Comm Fiscal Affairs, Automatic Exchange of Information: what it is, How it Works, Benefits, What Remains to Be Done, 2012):

1) The payer or the payer agent of the source country collects the income data payable to the non-resident of the source country. The tax authority usually can access the exchanged information when the non-resident of the source country credited the paid tax to the country where they reside (domicile).

2) The payer or payer agent report the information of the non-resident identity who receives income from the source country to the tax authority.
3) The tax authority consolidated all information on the nonresident from various countries and classify it to be sent to each country tax authority where the nonresident resides.

4) The information is encrypted and sent to each country where the nonresident resides.

5) The information is received and encrypted.

6) The origin country of the non-resident receives information automatically or manually.

7) The origin country of the non-resident analyze the information and take an action for compliance as needed.

AEOI can be used as a tool to manage the taxpayer disobedience who transfer their assets abroad in the form of investment or capital for a short period of time. AEOI can detect the taxpayer disobedience although the tax authority of the local country where the taxpayers are registered is not aware of any potential violation. Another benefit of AEOI is that it gives a sanction to any violation, increase compliance, and encourage the taxpayer to reveal their income in the foreign country to the tax authority where the taxpayer is registered (OECD, Comm Fiscal Affairs, Automatic Exchange of Information : what it is, How it Works, Benefits, What Remains to Be Done, 2012).

In general, AEOI ensures the same tax treatment on income from within the country and foreign country, by minimizing the possibility of tax reallocation into economic and financial resources. In addition, AEOI also educates the taxpayer on their obligation to submit the tax report, increase the government revenue and ensures all taxpayers fulfill their tax obligations fairly and punctual. (OECD, Comm Fiscal Affairs, Automatic Exchange of Information: what it is, How it Works, Benefits, What Remains to Be Done, 2012). Urinov in the Bulletin for International Taxation Journal (2015) described 
the implementation of new standards of automatic exchange of information that could be done in four steps by each country, i.e. (urinov, 2015):

1) The enactment of Common Report Standard (CRS) in the domestic law.

2) Selecting the legal basis for implementing the automatic exchange of information and deciding the bilateral and multilateral CAA basis.

3) Information technology infrastructure and regulation to collect and perform the exchange of information, which should follow the international standard.

4) To take an action when needed to ensure confidentiality, protection, and safety of the exchanged data.

\section{Common Report Standard (CRS)}

In an attempt to tackle tax avoidance practices and protect the integrity of the tax system, the government in all over the world introduce a new requirement for financial agency information collecting and reporting, namely Common Report Standard (Casi, Spengel and Stage, 2019). Common Report Standard or CRS is a standard of automatic financial information exchange for tax purposes including commentaries arranged by the Organization for Economic Cooperation and Development (OECD) along with the country members of G20 (Group of Twenty or G20) (Circular Letter of the Financial Services Authority No 16 / SEOJK.03/ 2017,2017).

Adopting the policy of Foreign Account Tax Compliance Act (FATCA) by the United States of America, many countries in the world have currently implemented the exchange of automatic financial account information which was introduced by FATCA to other countries besides USA, following its significant impact to counter the tax embezzlement issue in the USA to foreign countries. Therefore, CRS has become another version of FATCA to the nonUSA countries to implement the automatic exchange of information. CRS was introduced by the OECD in 2014 as a global standard to automatic exchange of information (AEol) implementation. The exchange of information involves a vast amount of data in numbers as well as written materials describing assets or income received by the taxpayer (PriceWaterhouseCoopers, 2018).

The exchange of information by request or spontaneous currently are conducted following the cases investigated by one of the tax authorities involved in the exchange of information. On the other hand, AEol enables the tax authority between countries to exchange the information automatically in a format agreed for a period of time, through a multilateral agreement. In addition, this step expands the scope of information being exchanged with a relatively complex bureaucratic procedure (PriceWaterhouseCoopers, 2018).

Meanwhile, FATCA operates under bilateral and multilateral agreements between the USA and each of its partners with two types of Competent Authority Agreement (CAA). Bilateral CAA is an exclusive agreement between two jurisdictions of the tax authorities, while the MCAA involves numerous jurisdictions to sign and each jurisdiction with all who sign the MCAA. Since June 4, 2015, 61 jurisdictions have signed the MCAA. This includes jurisdictions famous as the tax havens such as Switzerland and Cayman Islands, to join in 2017 or 2018. Indonesia is one of the countries that sign the MCAA. Therefore, the Indonesian financial agencies have the obligation to submit the CRS report with the first report due in September 2018 (PriceWaterhouseCoopers, 2018).

\section{The Implementation of Exchange of Information in The Banking Industry in Indonesia: The Case of XYZ BANK, LTD}

The Organization for Economic Cooperation and Development (OECD) published a series model article in the exchange of information for taxation purposes for the first 
time in 1963 titled as the Model of Double Taxation Convention on Income and Capital completed with Commentary in each article. The exchange of information is regulated in Article 26. Later in 1977, the OECD released a new version of the Convention Model with expanded scope and alteration in paragraph 1 Article 26 on the exchange of information that is sharing the required information and the party involved is the residence of one of the countries bound in the agreement (Contracting State).

There are three different ways to exchange the information, i.e. 1) by request; 2) spontaneous exchange of information; 3 ) the automatic exchange of information. In the beginning, the exchange of information to tackle tax avoidance and embezzlement practices were mostly conducted by request. However, the exchange of information by request was not very effective in practice since it requires long administrative procedure and time- consuming. This method was considered unable to keep up with tax avoidance and embezzlement practices that have become more aggressive and utilize advanced schemes. Therefore, the OECD and G20 countries initiated the implementation of the automatic exchange of information globally by declaring their commitments to end the bank confidentiality era for taxation purposes.

In the beginning, Indonesia mostly applied on request exchange of information. However, after the government of Indonesia signed the Convention on Mutual Administrative Assistance in Tax Matters (MAC) on November 3, 2011, in Cannes, France, the AEOI started to be implemented in Indonesia as it is regulated in one of the articles pertaining to AEOI implementation in Indonesia. Moreover, Indonesia also signed the Multilateral Competent Authority Agreement (MCAA) on June 3, 2015, in Paris, which indicates the government of Indonesia's eagerness to implement the AEOI for the first time in September 2018.

Indonesian commitment to implement the AEOI started in September 2018 is depicted by the publication of Regulation in Lieu of Law (Perpu) No.1 year of 2017 that was legalized to become the Law No.9 year of 2017 on the access of financial information for taxation purposes. Perpu No.1 year of 2017 regulates the rights of tax authority to access the financial information and the obligations of the financial and other financial services agencies and/or other entities to report the financial information automatically to the tax authority, perform the identification procedures of the financial account for reporting purpose, and provides sanctions for financial and other financial services agencies for disobedience to fulfill their reporting obligations.

The enactment of the domestic regulation, which regulates the implementation of the automatic exchange of information in Indonesia clearly depicts the effort of the government of Indonesia to fulfill the requirements set by the OECD, that is to adopt the OECD policies into the domestic regulations. The OECD also regulates the international standard for reporting, namely the Common Report Standard (CRS) which is then ratified into the Regulation of the Ministry of Finance (PMK) No.70/PMK.03/2017 and revised in PMK 19/PMK.03/2018 on the Technical Guidelines of Financial Information Access for taxation purposes, so that the financial agency as the first party with direct connection to the taxpayer financial report will have a legal basis in the technical guidelines for data collection and reporting which is being exchanged through the implementation of AEOI.

1) The individual self-certification.

This form is filled by the individual customer of the $\mathrm{XYZ}$ bank to confirm the customer's individual status according to the CRS

The entity CRS self-certification

This form is filled by the XYZ Bank's customer which is an entity to confirm the business status of the customer according to the CRS. 
2) The CRS self-certification for Controlling Person.

The form is used by the person who controls a particular entity (passive entities). The person is in charge of managing a particular institution and investment agency from the country/jurisdiction where the XYZ Bank located has not implemented CRS. This form should be filled by people who manage the entity through ownership or by any other means. The person in charge to control under particular condition will be titled as Senior Management Officer.

The XYZ Bank published a guideline in April 2016 to help the entity to fill out the CRS self-certification form. The guidelines are released to assist the customers to decide which classification is applicable for the entity as well as the controlling person. Other than classifying the customers data by their residential, the XYZ Bank as a Financial Agency informer should also classifies the account balance according to the limit of the balance that should be reported following the regulation of PMK No.19 year of 2018 Article 19 article (4) alphabet (a) that is an account that should be reported is an account of an individual customer with minimum balance one billion IDR by December, 31. Meanwhile, for an entity the rules follows PMK No.19 year 2018 paragraph 7 article (5) which states that 'excluded from the financial account that should be reported as mentioned in verse (2) that is one or more old financial account held by an entity as mentioned in article (2), with aggregated balance or the value of financial account no more than USD 250.000 on June, 30, 2018, December 31, 2018 and December 31 of each following year, which means each account held by an entity that has a minimum USD 250.000 balance by December 31 should be reported. On the other hand, the account classification for controlling person customer is made by looking at the tax obligation jurisdiction of the controlling person customer. If the controlling person tax obligation is in Indonesia, the financial account will be classified as the account that should be reported.

The first step taken by the XYZ Bank to collect the information pertaining to the AEOI is identifying the financial account by implementing the CRS rules through self-certification form as a part of CDD (customer due diligent) process. The XYZ Bank applies CDD to identify the domicile of the customers for taxation purposes for the individual as well as a controlling person. This is very important as the taxation is highly depended on the domicile of the customers and their tax obligation whether the customer is an Indonesian tax resident or not. In the Annex 1 alphabet D number 3 PMK No. 7 year of 2017 as it is revised in PMK No.19 year of 2018, it is described that the self-certification should be received during the opening of a new account since July 1, 2017 for the old financial account holder that has already opened an account before July 1, 2017. The Financial Services Agency informer should identify the customer's account according to the available data.

After the financial services agency informer received a valid self-certification from the customer, the financial services agency informer should confirm the genuineness of the submitted self-certification against the information received during the opening of the account. One of the procedures conducted during the process is CDD (Customer Due Diligence) by the financial services agency informer by following the anti-money laundering requirement or similar requirement where the financial services agency becomes the subject. During the due diligence procedure, the bank who serves as the financial services agency informer should follow the procedure according to the recommendations of FATF (The Financial Action Task Force) year of 2012

The obstacle encountered by the XYZ Bank is the limited coverage of the domestic regulation pertaining to the required $d$ that 
should be reported, thus the $\mathrm{XYZ}$ Bank utilizes the guidelines released by the OECD. Despite the publication of PMK.70/PMK.03/2017 which has been revised in PMK.19/PMK.03/2018 on guidelines for Financial Agency registration and Report Delivery of Automatic Financial Information which has fully adopted the requirements set by the OECD, there is still no specific rules to show that the adopted rules have been modified sufficiently to accommodate the domestic needs. Another obstacle is the data reporting to the related institutions where the $X Y Z$ Bank has found that the technical operation of the information system and the technological devices for reporting purposes are not stable, thus often leading to technical problems during the reporting process which indicates the poor reporting system that has not fulfilled the expectation.

The negative impact that was encountered by the $X Y Z$ Bank in the implementation of AEOI is the additional cost incurred to develop the system. Another impact is the additional tasks that should be carried by the $\mathrm{XYZ}$ Bank as well as other financial agency informers since they are obliged to make a report which is in favor of the tax authority, in this case, is the Directorate General of Taxes. Besides the impacts, there are some advantages gained by the XYZ Bank, that is with the exchange of information there is a global standard which is part of the safeguard released by the XYZ Bank to provide safety for the bank and customers from fraud and other financial crimes in the $X Y Z$ Bank global system. In one of the global standard points, there is a set of safeguards that regulates the transparency of the taxation. This is compatible with the objective of the AEOI which is to improve transparency in taxation. In an attempt to implement the safeguard, the $X Y Z$ Bank collects updated information on business activities and personal data of the customer, including the information that requires original documents from the customer. The XYZ Bank also obliges to ensure that the submitted information will only be used by the XYZ Bank and not to be used by the third party for marketing purposes.

By implementing the global standard, the $X Y Z$ Bank is able to estimate the risk level of the customer whether the customer is highly potential to commit fraud and/or financial crimes or not. The XYZ Bank will also be able to mitigate the possibility of tax embezzlement practices by a potential customer as well as the current customers of the XYZ Bank. This will influence the bank's appraisal because if the Bank has customers with high-risk level to commit fraud or financial crimes such as tax avoidance and embezzlement, this will have an impact to the bank's performance among the investors. The $X Y Z$ Bank will prefer to cooperate with customers who live in the countries that implement the AEOI since they have a lower risk of committing fraud and financial crimes compared to the customers who live in or the tax resident of the tax haven country.

\section{MANAGERIAL IMPLICATION}

Assessing the fact and the finding with regard to the implementation of exchange of information performed in Bank XYZ Ltd with respect to the Indonesian Tax Authority as the monitoring institution, thus the managerial implication of this policy:

1. The Directorate General of Taxes as the party with interest to report the data in the implementation of the automatic exchange of information should give more attention to the reporting procedure so it will not only a responsibility for the bank or financial agency informer. Each financial agency informer should have the same system applicable for all to provide easier administration for the financial agency informer.

2. On the other hand, there should be further guidance released by the Directorate General of Taxes as a competent authority that carefully 
regulates the guidelines for filling up the report, which will be submitted during the financial information reporting by the financial services agency informer.

\section{CONCLUSION}

Several points can be concluded from the research, i.e.:

1. The information collected by the XYZ Bank still encounters some technical problems and lack of support from domestic regulation pertaining to the technical procedure of creating the report. The impact of automatic exchange of information implementation is the additional cost incurred to develop the internal system following the applicable reporting standard and the additional tasks that should be covered by the $\mathrm{XYZ}$ Bank as the bank is required to report in favor of the tax authority, in this case, the Directorate General of Taxes.

2. The benefit received by the $X Y Z$ Bank is that the implementation of the AEOI is compatible with the global standard applied by the XYZ Bank. Global standard is a set of safeguard released by the XYZ Bank to provide safety for the bank as well as the customers from fraud and financial crimes in the XYZ Bank global system which also covers the transparency in taxation practice. The $X Y Z$ Bank prefers to cooperate with customers who live in the ountry that implement AEOI as they tend to have lower risk level compared to the customers who live in or the tax resident of the tax heaven country.

\section{REFERENCES:}

Adebisi \& Gbegi. 2013. Effect of Tax Avoidance and Tax Evasion on Personal Income Tax Administration in Nigeria, American Journal of Humanities and Social Sciences, Vol. 1, No. 3, pp. 125-134.

Akhtar Jahanzeb. 2018. Exchange of Information: Indian Experience, Developing Countries Implication, Tax Cooperation Policy Brief No. 4 September 2018.

Balafoutas, Beck, Krschbamer \& Sutter. 2015. The Hidden Cost of Tax Evasion: Collaborative Tax Evasion in Markets for Expert Services, Journal of Public Economics Vol. 192, pp. 14-25.

Casi E., Spengel Christoph and Stage. 2019. Cross-Border Tax Evasion After the Common Reporting Standard: Game Over? SSRN Electronic Journal.

Finansialku. 2017. Setelah Amnesti Pajak Berakhir: Kehadiran AEOI (Automatic Exchange Of Information) di Indonesia. Retrieved September 2018, 12, from www.finansialku.com: https://www.finansialku.com/setelah-amnesti-pajak-berakhir-kehadiran-AEol-automatic-exchangeinformation-di-indonesia/.

Gadzo Stephan and Kemenic Irena. 2017. Effective International Exchange as a Key Element of Modern Tax Systems: Promises and Pitfalls of the OECD's Common Reporting Standard, Public Sector Economics 41(2) pp. 207-226

Haradan Mohajan. 2018. Qualitative Research Methodology in Social Sciences and Related Subjects, Munich Personal RePEc Archive, MPRA Paper No. 85654.

OECD. 2006. Manual On The Implementation of Exchange of Information Provisions For Tax Purposes. OECD Publication.

OECD. 2012. Comm Fiscal Affairs, Automatic Exchange of Information: what it is, How it Works, Benefits, What Remains to Be Done. OECD Publication.

OECD. 2013. Action Plan on Base Erosion and Profit Shifting. OECD Publication.

OECD. 2014. Automatic Exchange of Information: A Roadmap for Developing Country 
OECD. 2018. Implementation Handbook Standard for Automatic Exchange of Financial Information in Tax Matter. OECD Publication.

Participation. Paris Global Forum on Transparency and Exchange of Information for Tax Purposes. Paris, France: OECD Publication

Peraturan Direktur Jenderal Pajak Nomor PER-67/PJ/2009 jo PER-28/PJ/2017 tentang Tata Cara Pertukaran Informasi Berdasarkan Permintaan Dalam Rangka Melaksanakan Perjanjian Internasional

Peraturan Pemerintah Keuangan Republik Indonesia Nomor 19/PMK.03/2018 Tentang Perubahan Kedua Atas Peraturan Menteri Keuangan Nomor 70/PMK.03/2017 Tentang Petunjuk Teknis Mengenai Akses Informasi Keuangan Untuk Kepentingan Perpajakan

Peraturan Pemerintah Pengganti Undang-Undang Republik Indonesia Nomor 1 Tahun 2017. (2017, Mei 08). Konsiderasi Peraturan Pemerintah Pengganti Undang-Undang Republik Indonesia Nomor 1 Tahun 2017. Jakarta, DKI Jakarta, Indonesia: Pemerintah Republik Indonesia

PriceWaterhouseCoopers, P. 2018. crs hought leadership. Retrieved Oktober 04, 2018, from www.pwc.com: https://www.pwc.com/id/en/publications/assets/financialservices/crs-hought-leadership.pdf

Urinov, V. 2015. Tax Amnesties as a Transitional Bridge to Automatic Exchange of Information. Bulletin for International Taxation, 168-176.

Vandenberg Paul and Myrold Alan. 2015. Exchange Information to Combat Tax Evation, ABD Institute Policy Brief No. 2015-3.

Yunadia, E. 2018. artikel dan opini kebijakan fiskal kaitannya dengan pertumbuhan ekonomi indonesia. Retrieved September 28, 2018, from www.kemenkeu.go.id: https://www.kemenkeu.go.id/publikasi/artikel-danopini/kebijakan-fiskal-kaitannya-dengan-pertumbuhan-ekonomi-indonesia 
